\title{
A systematic review of epidemiological patterns and proposed interventions to address pediatric burns in Nigeria
}

\author{
Srikanta Banerjee ${ }^{1}$, Constance Shumba ${ }^{2}$
}

\begin{abstract}
1. Walden University School of Health Sciences, 100 S Washington Ave \#900, Minneapolis, MN 55401.
2. Aga Khan University Department of Population Health and School of Nursing and Midwifery Nairobi, Kenya.
\end{abstract}

\begin{abstract}
Background: Unintentional injuries from burns comprise a significant proportion of public health morbidity in Nigeria. In order to understand the type and impact of burns on youth in Low-and-Middle-Income countries, the epidemiology of burns must be adequately assessed.

Methods: This review describes the epidemiological patterns of burn occurrences in the pediatric populations and proposes interventions using the Haddon Matrix to address injuries in specific populations in Nigeria. A literature search was conducted using the Proquest, CINAHL, and PubMed databases at the Johns Hopkins University library January 1, 1990 to August 14, 2018), on burns or thermal injury among pediatric populations in Nigeria. The review focused on the forms of injury, risk factors and potential interventions.

Results: Ten studies were identified and the main risk factors for burns were socioeconomic status, overcrowding, and involving young girls in traditional cooking roles. The main types of injuries include scald injuries (50\%) and fire burns (45\%) affecting mainly children aged 14 and below with significant regional epidemiological variations. We created a novel intervention to develop countermeasures and reduce the number of pediatric burns based on biological, physical and sociocultural environment..

Conclusion: Interventions such as improved supervision of children, improved emergency infrastructure and culturally sensitive first aid education and treatment can help ensure a reduction in morbidity and mortality resulting from burns. Epidemiological studies can provide an accurate depiction of the burden of burn injuries in different regions of Nigeria.

Keywords: Burns; unintentional injury; flame injuries; interventions; injury prevention; epidemiology.

DOI: https://doi.org/10.4314/ahs.v20i2.56

Cite as: Banerjee S, Shumba C. A systematic review of epidemiological patterns and proposed interventions to address pediatric burns in Nigeria. Afri Health Sci. 2020; 20(2): 991-999. https:// doi.org/10.4314/ abs.v20i2.56
\end{abstract}

\section{Introduction}

Burns can be defined as a type of unintentional thermal injury or trauma that can occur to the skin or any other type of tissue. Globally, 90 percent of burns occur in Low-and-Middle-Income-Countries (LMICs) ${ }^{1}$. In LMICs, the death rate is 4.3 per 100000 which is eight times higher than high income countries at 0.4 per 100 $000^{1,2}$. The three types of burn injuries that can occur are through liquid burn (scalds), solid burn (hot surface), or flame burn (fires) ${ }^{3-4}$. In some cases, smoke inhalational

\section{Corresponding author: \\ Srikanta Banerjee, \\ Walden University School of Health Sciences \\ 100 S Washington Ave \#900 Minneapolis, \\ MN 55401 \\ Email: skbanergt@gmail.com}

lung injuries are considered burn related injuries. There are several ways to classify burns including classification by cause, degree, body surface area, part of the body affected, and the extent of the burn ${ }^{5-9}$. While in developed countries, burns are coded by body surface area involved and the extent of third-degree surface, when creating burn registries in LMICs there is no methodical system ${ }^{10}$. Consequently, between 2014-2016, the International Society for Burn Injury (ISBI) created practice guidelines in an attempt to establish better surveillance and care in resource limited settings ${ }^{11}$.

Nigeria is the most populous country in Africa where the natural epidemiology of pediatric burns has not been previously characterized. In Nigeria, according to the World Health Organization, there were 21.2 per 100,000 deaths due to fires in 2012 among children less than 5 years of age 1 . In the same year, disability-adjusted life years (DALY) lost in Nigeria due to

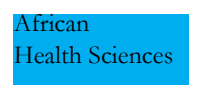

(C) 2020 Banerjee S et al. Licensee African Health Sciences. This is an Open Access article distributed under the terms of the Creative commons Attribution License (https://creativecommons.org/licenses/BY/4.0), which permits unrestricted use, distribution, and reproduction in any medium, provided the original work is properly cited. 
fires alone was 3540 per 100,000 individuals in children less than five. Fire safety is important to address as this causes considerable morbidity and mortality in Nigeria. Even though the prevalence of burns has increased due to urbanization, lack of literacy and poverty ${ }^{12}$, there have been no comprehensive reviews done on burn injuries in children in Nigeria in children. Additionally, traditional healers comprise a significant portion of the healthcare delivery within Nigeria, requiring burn treatment and prevention programs to incorporate this group.

The purpose of this article is to describe the epidemiological patterns of burn occurrences in the pediatric populations, identify different burn injury interventions that can apply to Nigeria, and apply the Haddon Matrix as a framework for improved injury prevention.

\section{Methodology}

A literature search was conducted using the Proquest, CINAHL, and PubMed databases at the Johns Hopkins University library and World Health Organization repositories (0-4), as well as journals that focus on trauma and burn care in children (0-18), through 2015. Inclusion criteria were; publication date from January 1 , 1990 through August 14, 2018, written in the English language, and a focus on burns or thermal injury as the primary discipline. Other search terms that were used were epidemiology, Nigeria, and pediatric. All reports on epidemiology were hospital based. Older publications were excluded due to inaccessibility and since they may not reflect the current state of burns and burn care in Nigeria.

The articles were reviewed and information extracted to Excel with regard to the region of the country, the epidemiological characteristics of the burns, the pattern of injuries as well as complications arising from burn injuries, and potential need for intervention. The modalities of management of patients reported in various articles were also retrieved, as was the outcome of burns management. While some authors defined a burn as a Total Body Surface Area (TBSA) of greater than $10 \%$, other authors defined a burn only when the patient was admitted to the hospital. Depending on the study, this review utilized both of the aforementioned criteria. Finally, a weighted prevalence estimate was calculated for scald injuries and flame injuries in the pediatric population in Nigeria.

Due to heterogeneity of the different studies, a formal meta-analysis was not possible. A thorough evaluation was conducted by two authors. Preferred Reporting Items for Systematic Reviews and Meta-Analyses (PRISMA) was used as a critical appraisal tool in order to further evaluate the importance of each review. The search yielded 96 articles. The process of article selection is summarized in Figure 1.

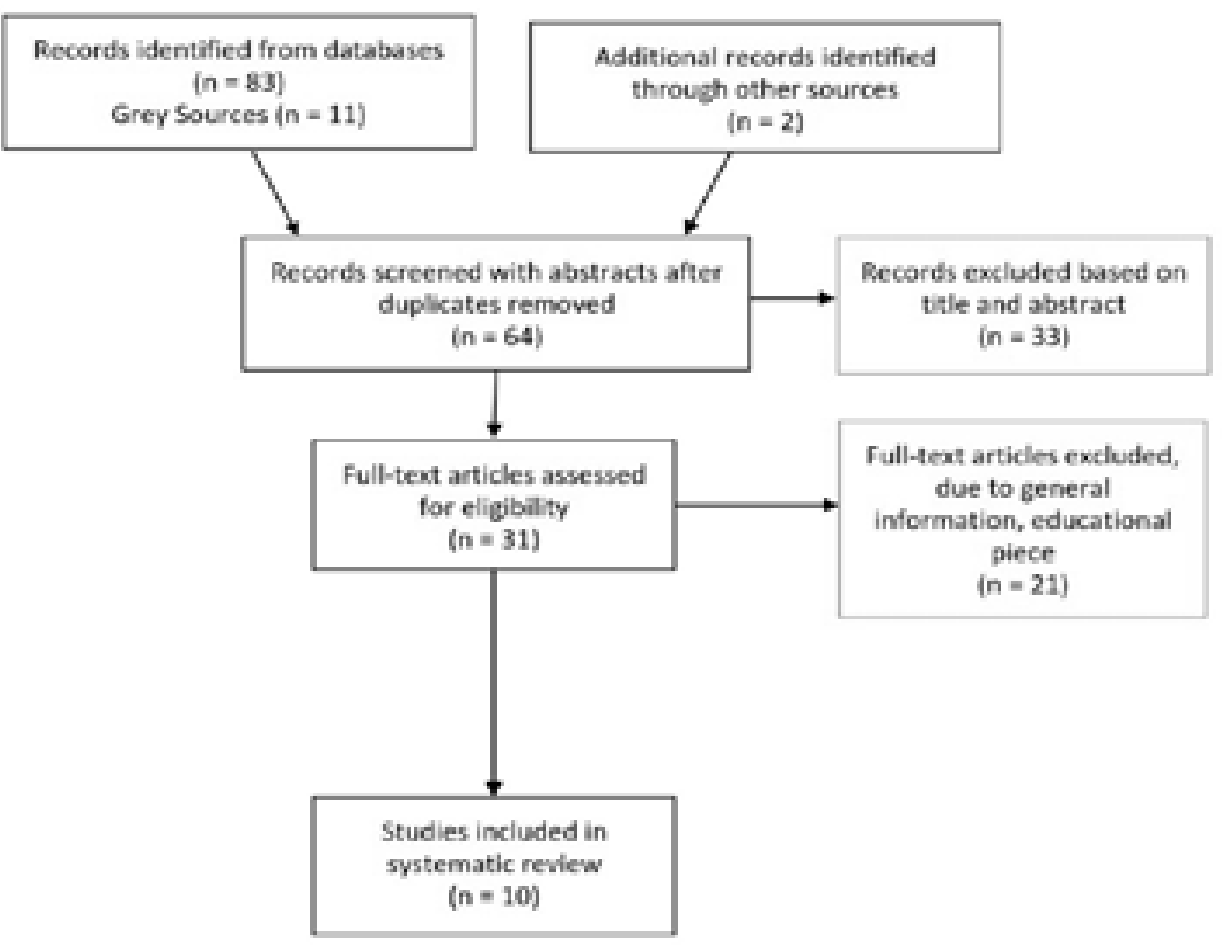

Pigure 1: Selection Process for Review Articles 
Summary of the epidemiological characteristics of Table 1: Epidemiological characteristics of child burn patients in
Nigeria

\begin{tabular}{|c|c|c|c|c|}
\hline Region & Authors(s) & Sample characteristics/ Findings & $\begin{array}{l}\text { Study } \\
\text { Design }\end{array}$ & Study Setting \\
\hline $\begin{array}{l}\text { Northeast } \\
\text { (Maidaguri) }\end{array}$ & Gali et al. 13 & $\begin{array}{l}\text { - Children below } 3 \text { years } \\
\text { disproportionately affected }(\mathrm{N}=219) \text {. } \\
64 \% \text { were accidental scald burns in } \\
\text { household. }\end{array}$ & $\begin{array}{l}\text { Retrospectiv } \\
\text { e Case } \\
\text { Series }\end{array}$ & $\begin{array}{l}\text { University of } \\
\text { Maiduguri } \\
\text { Teaching } \\
\text { Hospital }\end{array}$ \\
\hline
\end{tabular}

- Three females between ages 11-15 burned themselves as an attempted suicide to escape forced marriage

\begin{tabular}{|c|c|c|c|c|c|}
\hline $\begin{array}{l}\text { Northwest } \\
\text { (Sokoto) }\end{array}$ & Mungadi 14 & & $\begin{array}{l}\text { Children } \leq 15 \text { years old }(\mathrm{N}=108) \\
67 \% \text { were accidental scald burns in } \\
\text { household. }\end{array}$ & $\begin{array}{l}\text { Prospective } \\
\text { Cohort }\end{array}$ & $\begin{array}{l}\text { Usmanu Danfod } \\
\text { io University } \\
\text { Teaching } \\
\text { Hospital }\end{array}$ \\
\hline Northwest (Kano) & Uba et al. 15 & D & $\begin{array}{l}\text { Children } \leq 18 \text { years old }(\mathrm{N}=168) \\
70.2 \% \text { were caused by accidental } \\
\text { scald burn injuries }\end{array}$ & $\begin{array}{l}\text { Retrospectiv } \\
\text { e Cohort }\end{array}$ & $\begin{array}{l}\text { Jos University } \\
\text { Teaching } \\
\text { Hospital }\end{array}$ \\
\hline
\end{tabular}

\begin{tabular}{|c|c|c|c|c|c|}
\hline Southern (Lagos) & $\begin{array}{l}\text { Fadeyibi et al. } \\
16\end{array}$ & 一 & $\begin{array}{l}\text { Children } \leq 14 \text { years old }(\mathrm{N}=298) \\
66 \% \text { were accidental fire burns }\end{array}$ & $\begin{array}{l}\text { Retrospectiv } \\
\text { e Cohort }\end{array}$ & $\begin{array}{l}\text { Lagos State } \\
\text { University } \\
\text { Teaching } \\
\text { Hospital }\end{array}$ \\
\hline $\begin{array}{l}\text { Southern } \\
\text { (Calabar) }\end{array}$ & Asuquo et al. 18 & 一 & $\begin{array}{l}\text { Children } \leq 14 \text { years old }(\mathrm{N}=56) \\
73.1 \% \text { of the individuals are } \\
\text { preschool-age children } \\
52 \% \text { were accidental scald burns in } \\
\text { household }\end{array}$ & $\begin{array}{l}\text { Prospective } \\
\text { Cohort }\end{array}$ & $\begin{array}{l}\text { University of } \\
\text { Calabar } \\
\text { Teaching } \\
\text { Hospital }\end{array}$ \\
\hline
\end{tabular}

\begin{tabular}{|c|c|c|c|c|c|}
\hline Northern (Zaria) & $\begin{array}{l}\text { Kalayi \& } \\
\text { Muhammad, } \\
\text { 20; Kalayi } 21\end{array}$ & & $\begin{array}{l}\text { Children } \leq 3 \text { years old }(\mathrm{N}=84) \\
64 \% \text { were accidental scald burns in } \\
\text { household. } \\
27 \% \text { admitted to hospital for burn } \\
\text { injury, died from burns. }\end{array}$ & $\begin{array}{l}\text { Retrospectiv } \\
\text { e Cohort }\end{array}$ & $\begin{array}{l}\text { Ahmadu Bello } \\
\text { University } \\
\text { Teaching } \\
\text { Hospital }\end{array}$ \\
\hline Central (Irrua) & Dongo et al. 22 & D & $\begin{array}{l}\text { Children ages } 0-19 \text { comprised second } \\
\text { largest group }(\mathrm{N}=72) \\
\text { Adulterated kerosene high }(40 \%) \\
\text { etiology of fire burns }\end{array}$ & $\begin{array}{l}\text { Retrospectiv } \\
\text { e } \\
\text { Cohort }\end{array}$ & $\begin{array}{l}\text { Irrua Specialist } \\
\text { Teaching } \\
\text { Hospital }\end{array}$ \\
\hline
\end{tabular}

As demonstrated through Table 1, in central Nigeria, Dongo et al. ${ }^{22}$ found that among the 72 burn victims admitted to the hospital between 2001 to 2006, children ages 0-19 had the second highest rate of burns among different age groups. In southern Nigeria, Asuquo et al. ${ }^{18}$ assessed the epidemiology of burns in a teaching hospital in Calabar. Data for children admitted between 2005 and 2008 for burn injuries were included in the analysis. Out of 56 patients, the ages were between 9 days and 14 years with a mean age of 3.5 years. Among 
these individuals $73.1 \%$ were pre-school children. In southeastern, Okoro et al. ${ }^{19}$ found that the vast majority $(56 \%)$ of the children that suffered from burn injuries were five or younger.

Lagos is the largest city in Nigeria and the second fastest growing city in Africa, which is located on the southern part of the country. Fadeyibi et al. ${ }^{16}$ assessed the characteristics of pediatric burns between the years of 20042008 from birth to 14 years of age. Unlike the previous hospital-based studies, in this study, major burns were considered as involvement of over 10\% TBSA (Total Body Surface Area). They found that out of 298 chil- dren, a majority (40\%) of the cases occurred among the toddlers and $25.5 \%$ in the $2-5$ year age group. Ugburo et al. ${ }^{17}$ assessed the occurrence of neonatal injuries between 2004-2008 at four major tertiary health centers in Lagos and found the mean BSA to be $26 \%$ and out of the neonates the mean age was 16 days. In the northern part of Nigeria, in the city of Zaria, researchers from the largest teaching hospital in the country assessed the epidemiological burden of burns in the area between 1980 and $1987^{13,21}$. Out of the 207 patients who were admitted to the hospital, $40 \%$ of the deaths occurred in those individuals below the age of five.

\section{Types of burn injuries}

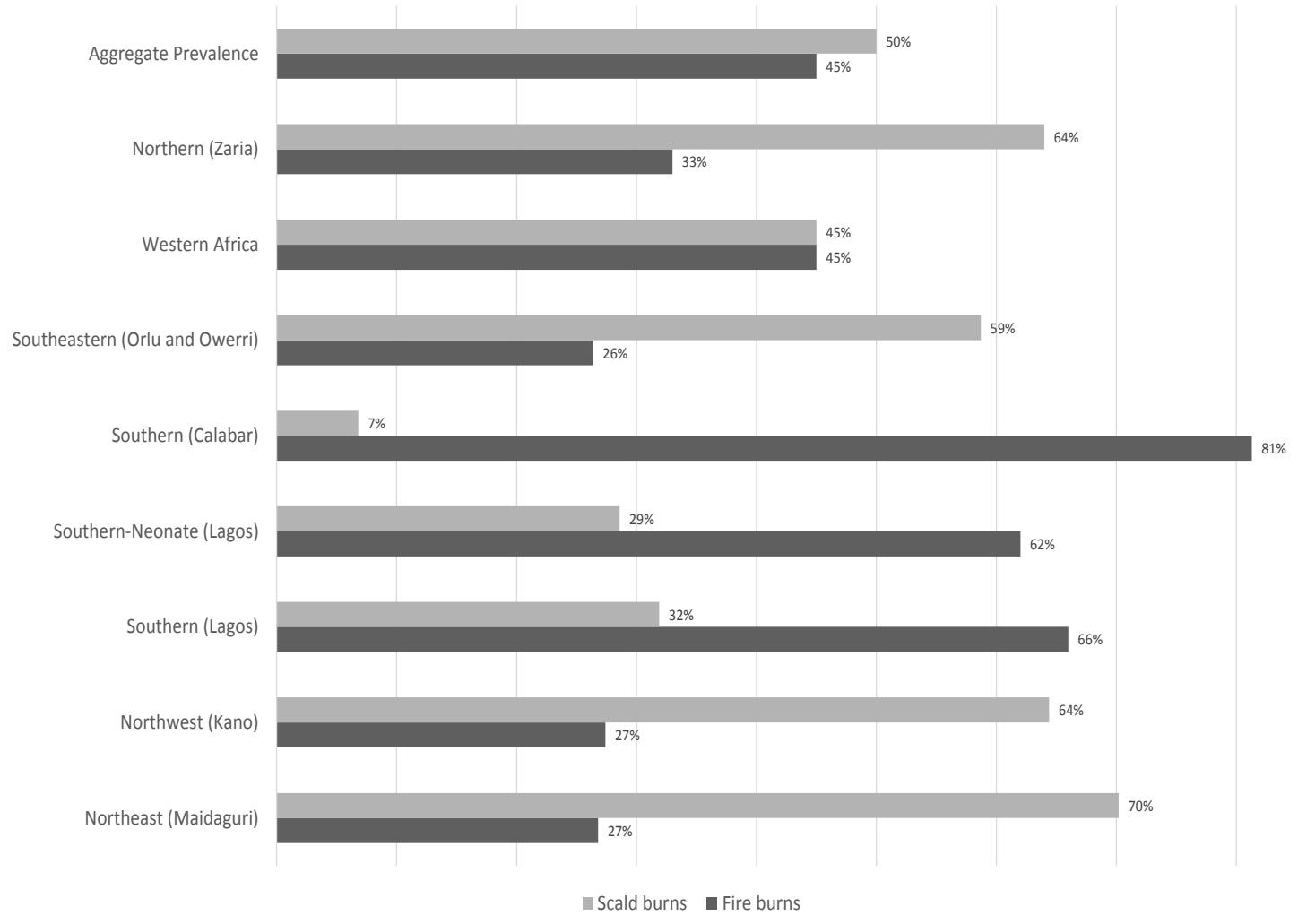

Figure 2: Types of burn injuries by geographic location

As seen in table 1 and figure 2, accidental fire and scald burns were among the leading causes of burn injuries. On a regional ${ }^{23}$ and aggregate national level, fire and scald burns are equally likely to occur at $45 \%$. However, as distribution of the types of burns are assessed locally, the percentages are not equal. In Lagos and Calabar fire burns were more commonplace, whereas in the rest of Nigeria, scald burns were the most common type of burn ${ }^{16-18}$. Additionally, at younger ages scald injuries are more commonplace than burn injuries mainly due to lack of safety measures and overcrowding. Additionally, in the dry winter months heating homes with adulterated kerosene was cited as a major predisposing factor for fire burns in different areas of Nigeria.
Lagos and central Nigeria had different types of burns etiology reported than other regions of Nigeria. More specifically, Dongo et al. ${ }^{10}$ found that $40 \%$ of their sample in central Nigeria had injuries between the cold and dry seasons of November and January. Some of this is attributed to adulterated kerosene used to heat homes. Kerosene burns resulted from explosion of lanterns and stoves during the process of refilling. The adulteration of kerosene takes place deliberately with the intention of making more profit from a specific amount. Additionally, in Lagos, the vast majority (59\%) was caused by an injury from fire explosions from kerosene lanterns, cooking stoves, and electricity generating machines ${ }^{16-17}$. 
Fires and hot liquids were the primary and secondary causes of mortality in the age group. Additionally, among neonates, Ugburo et al. ${ }^{17}$ found open flame thermal injuries to be the major $(62 \%)$ cause of burn injuries. While fire burns among the children is a primary cause of morbidity in certain regions of Nigeria, in southern and northern Nigeria scald burns are more common. For instance, in southern Nigeria, Asuquo et al. (2008) found that out of their patient sample, $69.6 \%$ sustained scald injuries, while $30.4 \%$ suffered fire injuries. These scald injuries were attributed to accidental burns from boiling water in the kitchen. According to Asuquo et al. ${ }^{18}, 52 \%$ of the injuries were suffered by those below the age of 5 , specifically from scald injuries. Scald injuries were mainly attributed to cooking on the floor. Okoro et al. 19 also found that burn injuries among children $(58.7 \%)$ were primarily from scald injuries. Children hover around the kitchen and get injured by boiling water during the preparation of food. The predominant source of burns is different between different regions of Nigeria.

As seen in Figure 1, when the aggregate prevalence of burns was calculated, the percentage of burns due to fire injuries was found to be $45 \%$ while the percentage due to scald injuries was found to be $50 \%$. While there are differences in etiology in different regions of $\mathrm{Ni}$ geria, the aggregate prevalence of each type of burn is similar.

\section{Severity of burn injuries}

There were varying levels of burn severity suffered by different patient populations. This measure was assessed differently by various researchers. Gali et al. ${ }^{13}$ defined major burns as the types of burns that caused major disability and mortality. They found that $60 \%$ of the burns were classified as major and led to a mortality rate of $16 \%$. Fadeyibi et al.16 found that the mean TBSA was $29.67 \%$ and the primary $(48.3 \%$ ) cause of death in this study population was asphyxia from fire burns.

\section{Predisposing factors}

In order to demonstrate predisposing factors more systematically, a Haddon Matrix (Table 2) specific to Nigeria was constructed based on available literature. This matrix helps to indicate which part of the problem can be addressed in order to device appropriate prevention methods ${ }^{24}$. For instance, if there is knowledge that the Harmattan season, which is cold and dry will cause more fires, then more public knowledge campaigns can be implemented during this season.

\section{Table 2: Haddon Matrix as applied to risk factors for fire related burns in Nigeria}

\begin{tabular}{llll}
\hline & Pre-event & Event & Post-event \\
Biological Event & $\begin{array}{l}\text { Lack of supervision, and } \\
\text { physical and congenital } \\
\text { disabilities }\end{array}$ & $\begin{array}{l}\text { Lack of smoke alarms, } \\
\text { no knowledge of } \\
\text { evacuation procedures }\end{array}$ & $\begin{array}{l}\text { Lack of first aid kits, Lack of knowledge } \\
\text { as to what to do right after a burn }\end{array}$ \\
\hline
\end{tabular}

\begin{tabular}{llll}
$\begin{array}{l}\text { Physical } \\
\text { Environment }\end{array}$ & $\begin{array}{l}\text { Lack of smoke alarms, no } \\
\text { knowledge of evacuation } \\
\text { procedures, Need for } \\
\text { heating increases in cold, } \\
\text { dry Harmattan season 10. }\end{array}$ & $\begin{array}{l}\text { Lack of escape routes, } \\
\text { lack of access to help }\end{array}$ & $\begin{array}{l}\text { Lack of access to water, Poor response } \\
\text { time to emergency request } 16\end{array}$ \\
Sociocultural & $\begin{array}{l}\text { Traditional gender roles } \\
\text { Environment in kitchen); }\end{array}$ & $\begin{array}{l}\text { Lack of access to } \\
\text { information or } \\
\text { suicide to escape child } \\
\text { marriage 13; deliberate } \\
\text { burncy heated to treat } \\
\text { sonstems 11 }\end{array}$ & $\begin{array}{l}\text { Lack of access to special burn care unit, } \\
\text { Lack of infrastructure }\end{array}$ \\
\hline
\end{tabular}

\section{Outcomes and costs}

In Nigeria, researchers found that burns led to considerable morbidity and disability. Infections from Pseudomonas spp. and Staphylococcus spp. were com- monplace. Multidrug-resistant wound infections by different types of bacteria were found to be a common complication of burns ${ }^{20,26}$. While data on children was scant, in the general population of Nigeria, post-burn 
contractures and hypertrophic scars $22 \%$ in Northern Nigeria) were a common late complication of burn injury in Nigeria, with the anterior neck being a common $\operatorname{site}^{26}$. There were psychological side effects of depression and anxiety reported in $65 \%$ of patients. Similarly, researchers found detrimental psychological consequences from traumatic stress reactions to behavioral problems in children exposed to burns in different parts of the world ${ }^{27}$.

Along with long-term morbidity, the cost of caring for burn victims is prohibitive for an average Nigerian. Considering that an average Nigerian burn victim earns less than $\$ 5$ a day, in the city of Lagos, the average cost (\$1054) of care was not affordable ${ }^{16}$. Ahachi et al. ${ }^{28}$, found the cost was attributed to dressings, drugs, and hospital admissions during the acute phase of hospital management. When researchers included the cost of physical therapy, surgeries, and investigations in the non-acute phase of the burn, the costs ballooned to $\$ 54,624$. The length of stay was longer for burn victims than other admissions, some being up to a year.

\section{Potential intervention proposals}

Through this intervention-based review, two novel programs have been proposed to target and potentially reduce the number of pediatric burns. One program takes a health belief approach while the other program would take a structural approach.

\section{FAiTH (First Aid in Traditional Healers) program}

Traditional healers comprise a considerable component of primary health care delivery, due to the lack of affordability of trained physicians. In Nigeria, $60 \%$ of children with a fever consult a traditional healer for first line of treatment $\mathrm{t}^{29}$. The FAiTH education program will emphasize the harm in using engine oil, palm oil, dry salt, or raw eggs which is still commonly used as traditional treatment ${ }^{26}$. This re-education of traditional healers will allow the common myths to be dispelled in the population. This will be replaced with education focusing on how to provide first aid on scald and fire burns, since these are the most common causes of burn injuries. They would be educated to "cool the burn" or run cool water over the burn for 10 to 20 minutes, use first aid, and not to use ice. This education will spread through the mass media channels.

Petroleum stove-related Harm and Injury Reduction Education (PHIRE safety program)

Distribution by antenatal care providers of safe compressed gas stove burners which self-extinguish when they are knocked over will help prevent fires. A Primus burner would transition to an LPG burner ${ }^{30}$. Additionally, mothers can be provided vouchers for Liquefied Petroleum Gas (LPG) rather than kerosene fuel as LPG causes less mortality. The LPG cylinder and burner would be located in close proximity so that there would be less chances of leakage. In a teaching hospital, out of all burns, $32 \%$ were attributed to fires from Primus burners, demonstrating a need to provide safer fire sources for cooking ${ }^{31}$. Mothers will also need education on proper storage of flammable substances. Parents will be educated about better supervision of children in the kitchen and how to use a portable burner safely.

\section{Rationale for interventions}

While both proposals are potentially beneficial, we will expound more on the FAiTH program as this is potentially more cost-effective. By retraining traditional healers about the advantages of cooling scald burns, trained health workers will open communication with traditional healers so that their health practices complement each other. Consequently, through the FAiTH program, the education on how to treat scald burn injuries will be communicated to families as they come to visit the traditional healers. According to researchers, proper water first aid related to burns results in significant reduction in injury ${ }^{16}$. While without water first aid, the complication rate was $35 \%$, with water first aid the complication rate was $18 \%$ in Lagos, Nigeria. Ytterstad and Sogaard ${ }^{32}$ found improvements after first aid interventions in different populations.

\section{Cost-effectiveness and sustainability through tra- ditional healers}

Due to the main component of FAiTH program being education, this would be considered affordable when compared to the long-term costs that are attributed to the long-term health care costs from burns and scald injuries. Government officials, policymakers, and stakeholders need to be made aware of the FAiTH program and must work cohesively with the traditional healers. The Nigerian Ministry of Health is looking to decrease the mortality of children under five, as this is high in comparison to other countries in sub-Saharan Africa ${ }^{33}$. By addressing burn injuries in children, the mortality rate can be reduced.

Traditional healers have an interest in understanding burns and fire, as fire is an integral part of the cultural context of the Nigerian people. The Yoruba ethnicity has a fire deity Sango who is honored in August. Fire safety can be integrated with Sango and August 
can be made fire safety education month. Additionally, the Hausa tribe in the North uses fire in many of the old traditions. Due to the importance of the accidental fire injury, the Ministry of Health needs to consider fire safety as part of public health infrastructure. The National Board for Technical Education is training in Paramedics technology and can include first aid training to traditional healers ${ }^{34}$.

\section{Outcomes and Challenges}

The expected outcome of the FAiTH program is that as traditional healers are educated about the need to "cool the burn." This knowledge will "trickle down" to the patients as they see them. They can organize education sessions and information fairs that would educate others about first aid for scald and fire burns. However, there may be challenges in the process. Firstly, there may be resistance by traditional healers to embrace the idea that cooling the burn is important for scald burns. Due to their mistrust of Western medicine, education of traditional healers may need to be culturally sensitive $^{35}$. Instead of using a traditional scientific construct, traditional healers may need other methods to convince why raw eggs do not alleviate burn injuries. Secondly, traditional knowledge that has been passed down between generations may be difficult to challenge and reverse as this may be perceived as challenging cultural and societal orthodoxy. Lack of literacy may lead to mistrust of other forms of knowledge. Contextualizing the information in the form of stories and songs may allow the information to subtly integrate into the culture.

\section{Discussion}

The review identified nine articles with more than 1079 cases of burns based on the hospital and community-based data used in the identified studies ${ }^{13-22}$. One of the key findings of this intervention-based review is that burns disproportionately affect children aged 0 and 14 years. The main types of burns experienced were fire burns and scald burns. Out of the studies with complete data, the aggregate prevalence of fire-related burns was $45 \%$, while the aggregate prevalence of scald burns was $50 \%$. While the main reason for fire burns stems from a combination of dry season and unsafe heating sources in cold winter months, scald burns stem from traditional gender roles and cooking on the kitchen floor. Lack of knowledge, lack of infrastructure, and sociocultural factors were identified as predisposing factors for burns.
Potential interventions should focus on distributing safer types of cooking burners, educating the public on safe storage, and addressing first aid knowledge based on modern medicine rather than the paradigm of traditional healers. The paucity of studies and data leads to difficulties in creating public health interventions adequately. Out of all of the studies in the review, only one study evaluated cases from community clinics ${ }^{24}$. Hospital-based registries only capture more severe burns that required hospitalizations. Additionally, the World Health Organization has implemented an international Global Burn Registry in which some hospitals from Nigeria have registered36. This surveillance system requires more collaboration from other hospitals. Community level surveillance of burn injuries would provide more information about the etiology of burns in ths age group.

\section{Conclusion}

Burn-related injuries in the pediatric population are a neglected public health issue that requires more attention in Nigeria. As more and more Nigerian states implement the National Health Insurance Scheme, the focus on prevention can lead to higher levels of preventative measure like higher levels of fire safety. Since many of the Millennium Development Goals (MDGs) and Sustainable Development Goals (SDGs) address the intention to decrease mortality in this population, countries like Nigeria should invest more resources in establishing a national registry to complement international efforts for burn-related injuries and identifying which types of burns affect different regions ${ }^{37}$. Additionally, more resources need to be invested in educating the public on carrying and storing petroleum to prevent accidents. Finally, traditional healers and the general population should be educated about the proper ways to provide first aid to burn victims, once the injury has occurred.

\section{Declarations}

Ethics approval and consent to participate

Not applicable.

\section{Consent for publication}

Not applicable.

\section{Availability of data and material \\ Not applicable.}

\section{Competing interests}

Non declared. 


\section{Funding}

This work did not receive any funding support.

\section{Authors' contributions}

Both (SB and CS) contributed to the review process of the articles. SB drafted the manuscript and CS provided further insights about global health to improve the manuscript.

\section{Acknowledgements}

Not applicable.

\section{Authors' information}

Both SB and CS teach public health. Additionally, SB received postdoctoral training from Johns Hopkins Bloomberg School of Public Health in the area of Global Health.

\section{References}

1. WHO. Estimates for 2000-2012: Cause Specific Mortality WHO Internet. 2013 cited 15.07.19. Available from: http://www.who.int/healthinfo/global_burden_disease/estimates/en/index1.html.

2. Hundeshagen G, Wurzer P, Forbes AA, Cambiaso-Daniel J, Nunez-Lopez O, Branski LK, Herndon DN. Burn prevention in the face of global wealth inequality. Safety in Health 2016;2:1.

3. Forjuoh SN. Burns in low- and middle-income countries: A review of available literature on descriptive epidemiology, risk factors, treatment and prevention. Burns 2006;32:529-537.

4. Golshan A, Patel C, Hyder AA. A systematic review of the epidemiology of unintentional burn injuries in South Asia. Journal of Public Health 2013;14:fds102.

5. Krishnamoorthy V, Ramaiah R, Bhananker SM. Pediatric burn injuries. International Journal of Critical Illness and Injury Science 2012;2:128.

6. Suvarna M, Niranjan UC. Classification methods of skin burn images. International Journal of Computer Science \& Information Technology 2013;5:109.

7. Serrano C, Boloix-Tortosa R, Gómez-Cía T, Acha B. Features identification for automatic burn classification. Burns 2015;41:1883-90.

8. Abraham JP, Plourde BD, Vallez LJ, Nelson-Cheeseman BB. Correcting a prevalent misunderstanding of burns. Burns 2016;42:715-6.

9. Osborne CL, Petersson C, Graham JE, Meyer WJ, Simeonsson RJ, Suman OE, Ottenbacher KJ. The multicenter benchmarking study of burn injury: A content analysis of the outcome measures using the internation- al classification of functioning, disability and health. Burns 2016;42:1396-403.

10. Dongo AE, Irekpita EE, Oseghale LO, Ogbebor $\mathrm{CE}$, Iyamu CE, Onuminya JE. A five-year review of burn injuries in Irrua. BMC Health Services Research 2007;7:171. http://doi:10.1186/1472-6963-7-171.

11. Peck M, Falk H, Meddings D, Sugerman D, Mehta S, Sage M. The design and evaluation of a system for improved surveillance and prevention programmes in resource-limited settings using a hospital-based burn injury questionnaire. Injury Prevention 2016;22:156-62.

12. Rode, H, Berg, A, \& Rogers, A. Burn care in South Africa. Ann Burns Fire Disasters 2011;24:7-8.

13. Gali BM, Madziga AG, Naaya HU. Epidemiology of childhood burns in Maiduguri north-eastern Nigeria. Niger J Med 2004;13:144-7.

14. Mungadi IA. Childhood burn injuries in north western Nigeria. Niger J Med 2002;11:30-2.

15. Uba AF, Edino ST, Yakubu AA. Paediatric burns: management problems in a teaching hospital in north western Nigeria. Trop Doct 2007;37:114-5.

16. Fadeyibi IO, Mustapha IA, Ibrahim NA, Faduyile FI, Faboya MO, Jewo PI, et al. Characteristics of paediatric burns seen at a tertiary centre in a low income country: A five year (2004-2008) study. Burns 2011;37:528-34.

17. Ugburo AO, Fadeyibi IO, Mofikoya BO, Akanmu ON, Temiye EO, Kanu OO, et al. Neonatal burns in Lagos, South-Western Nigeria: Epidemiology and outcome of management. Burns 2013;39:483-92.

18. Asuquo ME, Ngim O, Agbor C. A prospective study of burn trauma in adults at the University of Calabar Teaching Hospital, Calabar (South Eastern Nigeria). Eplasty 2008;8:370-6.

19. Okoro P, Igwe P, Ukachukwu A. Childhood burns in south eastern Nigeria. African Journal of Paediatric Surgery 2009;6:24.

20. Kalayi GD, Muhammad I. Burns in children under 3 years of age: the Zaria experience. Annals of Tropical Paediatrics 1996;16:243-8.

21. Kalayi GD. Mortality from burns in Zaria: an experience in a developing economy. East Afr Med J 2006;83:461-4.

22. Gali BM, Madziga AG, Naaya HU. Epidemiology of childhood burns in Maiduguri north-eastern Nigeria. Niger J Med 2004;13:144-7.

23. Nthumba PM. Burns in sub-Saharan Africa: a review. Burns 2016;42(2):258-66.

24. Fadeyibi IO, Ibrahim NA, Mustafa IA, Ugburo AO, Adejumo AO, Buari A. Practice of first aid in burn related injuries in a developing country. Burns 2015;41:132232. 
25. Deljavan R, Homayoun S-B, Nasrin F, Shahnam A, Mohammadi,. Application of Haddon's Matrix in Qualitative Research Methodology: An Experience in Burns Epidemiology. International Journal of General Medicine 2012;5:621-27. http://doi:10.2147/IJGM.S34394.

26. Oladele AO, Olabanji JK. Burns in Nigeria: a review. Annals of burns and fire disasters. 2010;23:120.

27. Bakker A, Maertens KJP, Van Son MJM, Van Loey NEE. Psychological consequences of pediatric burns from a child and family perspective: a review of the empirical literature. Clin Psychol Rev 2013;33:361-71.

28. Ahachi CN, Fadeyibi IO, Abikoye FO, Chira MK, Ugburo AO, Ademiluyi SA. The direct hospitalization cost of care for acute burns in Lagos, Nigeria: a one-year prospective study. Ann Burns Fire Disasters 2011;24:94-101.

29. Abdullahi AA. Trends and Challenges of Traditional Medicine in Africa. Afr J Tradit Complement Altern Med 2011;8:115-23.

30. Ahuja RB, Dash JK, Shrivastava P. A comparative analysis of liquefied petroleum gas (LPG) and kerosene related burns. Burns 2011;37:1403-10.

31. McGlone ER, Goutos I, Nelson RA, Pandya A.
Primus stove burns: a persisting problem in developing countries. Int J Burns Trauma 2011;1:11-6.

32. Ytterstad B, Søgaard AJ. The Harstad Injury Prevention Study: prevention of burns in small children by a community-based intervention. Burns 1995;21:259-66. 33. Antai D. Inequalities in under-5 mortality in Nigeria: do ethnicity and socioeconomic position matter?. Journal of Epidemiology 2011;21:13-20.

34. Umar IY, Ma'aji AS. Repositioning the Facilities in Technical College Workshops for Efficiency: A Case Study of North Central Nigeria. Journal of STEM Teacher Education 2016;47:6.

35. Mutungi E, Kioli FN, Mulemi BA. Healed and Crippled: The Effect of Global Medicine on African Indigenous Treatment and Care Approaches. Journalism 2015;5:471-9.

36. WHO. Global Burn Registry Internet. 2013 cited 15.07.19. Available from: https://www.who.int/violence_injury_prevention/burns/gbr/en/.

37. Simon GL, Bailis R, Baumgartner J, Hyman J, Laurent $\mathrm{A}$. Current debates and future research needs in the clean cookstove sector. Energy for Sustainable Development 2014;20:49-57. 